\title{
Synthesis and Biological Activity of Engineered $\mathrm{SiO}_{2}$ Nanomaterials
}

\author{
Oliwia Metryka ${ }^{1}$, Daniel Wasilkowski ${ }^{1}$, Anna Nowak ${ }^{2}$, Mateusz Dulski ${ }^{2}$, Malgorzata Adamczyk- \\ Habrajska $^{2}$, Agnieszka Mrozik ${ }^{1}$ \\ ${ }^{1}$ Institute of Biology, Biotechnology and Environmental Protection, Faculty of Natural Sciences, University of Silesia, \\ Jagiellońska 28, 40-032 Katowice, Poland \\ oliwia.metryka@us.edu.pl; daniel.wasilkowski@us.edu.pl; agnieszka.mrozik@us.edu.pl \\ ${ }^{2}$ Institute of Materials Engineering, Faculty of Science and Technology, University of Silesia, \\ 75 Pułku Piechoty 1a, 41-500 Chorzów, Poland \\ anna.m.nowak@us.edu.pl; mateusz.dulski@us.edu.pl; malgorzata.adamczyk-habrajska@us.edu.pl
}

\begin{abstract}
The multi-disciplinary use of nanomaterials in everyday products has led to their release into the environment, where they can pose a threat to living organisms, including microorganisms. Currently, the level of new nanomaterials exceeds the set of available information about their potential toxicity. Therefore, it is of the greatest importance and challenge for future research to carry out nanotoxicological studies in order to expand the knowledge about their biological activity. The aim of this study was to evaluate the potential toxic effect of newly synthesized $\mathrm{nSiO}_{2}$ nanoparticles and the $\mathrm{nCu} / \mathrm{SiO}_{2}$ nanocomposite against selected microorganisms. For this purpose, traditional toxicological methods using reference bacteria Escherichia coli and Bacillus subtilis as well as Microbial Assay for Risk Assessment (MARA) were performed. The study showed that $\mathrm{nSiO}_{2}$ had a greater antibacterial impact on reference strains than $\mathrm{nCu} / \mathrm{SiO}_{2}$. In addition to this, B. subtilis was more sensitive to nanomaterials than E. coli. Ecotoxicological MARA test showed that the tested nanomaterials exhibited low antibacterial activity and none of them had antifungal activity. SEM imaging indicated that both nanomaterials formed irregularly shaped agglomerates.
\end{abstract}

Keywords: Nanomaterials, Microorganisms, Toxicity, Risk assessment, Scanning electron microscope imaging

\section{Introduction}

Although naturally occurring nanomaterials have existed in nature for a very long time, products and modern technologies with 'nano' prefixes have only recently become very popular. Modern technological solutions at a nanometric scale and the huge potential for their implementation in various economic sectors have initiated a new era of the industrial revolution in the 21 st century. Nowadays, there is an extensive production of different engineered nanomaterials, which are used in everyday products and many advanced technological processes. For this reason, there is a potential risk of their release and accumulation in various ecosystems. It is well documented that living organisms can adapt to the presence of nanoparticles of a natural origin, however, the impact of man-made nanomaterials on their functioning is relatively little known. Moreover, there is no agreed upon protocol for testing the potential impact of nanomaterials on the environment and living organisms. Hence, it is of the greatest importance to carry out case studies to learn and comprehend the biological activity of these structures. Since nanomaterial hazards cannot be categorised and toxicity testing methods are not standardized, an individual risk assessment by many authors is used [1,2].

The objective of this study was to examine the biological activity of chemically synthesised $\mathrm{nSiO}_{2}$ nanoparticles and the $\mathrm{nCu} / \mathrm{SiO}_{2}$ nanocomposite against two model bacteria species Escherichia coli and Bacillus subtilis. Also, to assess the antimicrobial activity of the $\mathrm{nSiO}_{2}$ and $\mathrm{nCu} / \mathrm{SiO}_{2}$ against phylogenetically unrelated microorganisms, the Microbial Assay for Risk Assessment (MARA) was performed.

\section{Materials and methods}

\subsection{Synthesis of $\mathrm{SiO}_{2}$ nanomaterials}

The $\mathrm{nCu} / \mathrm{SiO}_{2}$ were synthesized and made available by the Institute of Material Engineering, University of Silesia, Poland. Commercially available $\mathrm{nSiO}_{2}$ were obtained from the US Research Nanomaterials Inc. (USA). For the chemical synthesis of the $\mathrm{nCu} / \mathrm{SiO}_{2}, \mathrm{nSiO}_{2}$ were used as an oxide matrix for the attachment of the $\mathrm{nCu}$. The $\mathrm{nCu}$ were prepared via a 
chemical reduction method using $\mathrm{Cu}\left(\mathrm{CH}_{3} \mathrm{COO}\right)_{2}$ as $\mathrm{Cu}$ ions donor, ascorbic acid as the reducer and ammonia solution for the stabilization of synthesized nanoparticles. The synthesis of $\mathrm{nCu} / \mathrm{SiO}_{2}$ required prior introduction of prepared $\mathrm{nCu}$ to the aqueous solution of $\mathrm{nSiO}_{2}$ with the addition of $10 \% \mathrm{NaOH}$. The suspension was mixed using a magnetic stirrer and then filtered through a polyethylene filter. The precipitate was washed with distilled water and ethanol, and dried at room temperature resulting in the formation of nanopowder [3].

\subsection{Scanning electron microscopy}

The morphology of nanomaterials was observed using a scanning electron microscope (SEM). Aqueous solutions of nanomaterials were transferred to graphite tapes, stained with technical gold and observed under a microscope (JEOL JSM-7100F with an accelerating voltage of $15 \mathrm{kV}$ and a vacuum of $9.6 \cdot 10^{-5} \mathrm{~Pa}$ ).

\subsection{Potential toxicity of nanomaterials}

Antibacterial activity of $\mathrm{nSiO}_{2}$ and $\mathrm{nCu} / \mathrm{SiO}_{2}$ was studied against two bacteria species $E$. coli $\left(\mathrm{ATTC}^{\circledR} 25922^{\mathrm{TM}}\right.$ ) and B. subtilis (ATTC ${ }^{\circledR} 6633^{\mathrm{TM}}$ ) using a traditional plate method [3]. For this purpose, bacteria were grown in a LuriaBertani medium (LB) for $3-4 \mathrm{~h}\left(37^{\circ} \mathrm{C}, 130 \mathrm{rpm}\right)$ to reach the mid-exponential growth phase. Next, bacterial cells were inoculated into fresh LB $\left(\mathrm{OD}_{600}=0.1\right)$ and appropriate nanomaterials in the concentration range of 10 to $1500 \mathrm{mg} \mathrm{L}^{-1}$ were added. Bacterial cultures with and without the addition of $\mathrm{nSiO}_{2}$ and $\mathrm{nCu} / \mathrm{SiO}_{2}$ (control samples) were incubated for $24 \mathrm{~h}\left(37^{\circ} \mathrm{C}, 130 \mathrm{rpm}\right)$. After this time, 10 -fold dilution series were made from each culture in $0.85 \%$ saline solution and transferred $(100 \mu \mathrm{l})$ on LB agar plates. After 24 hours of incubation at $37^{\circ} \mathrm{C}$, the grown single colonies were counted. Microbial inhibitory concentration (MIC) and minimum bactericidal concentration (MBC) were determined based on $99 \%$ and $100 \%$ inhibition of bacteria growth, respectively, in comparison with their growth in a control sample. In contrast, the half maximal inhibitory concentration $\left(\mathrm{IC}_{50}\right)$ was determined using the Prism 5 program (GraphPad Software, USA).

\subsection{Microbial Assay for Risk Assessment (MARA)}

The MARA test was used to assess the toxicity of $\mathrm{nSiO}_{2}$ and $\mathrm{nCu} / \mathrm{SiO}_{2}$ on 11 different microbial strains from diverse environmental niches. A MARA plate was independently prepared for each type of nanomaterial with final concentrations of 5 to $1000 \mathrm{mg} \mathrm{L}^{-1}$. After an 18-hour incubation, the MARA plates were scanned using a HP PrecisionScan Pro scanner and analysed using the MARA program. Assessment of the overall toxicity of nanomaterials was expressed as a microbial toxic concentration (MTC, $\mathrm{mg} \mathrm{L}^{-1}$ ).

\section{Results and discussion}

Scanning electron microscopy imaging of the $\mathrm{nSiO}_{2}$ and $\mathrm{nCu} / \mathrm{SiO}_{2}$ structure showed that both nanomaterials tended to form irregularly shaped agglomerates (Fig. 1). This tendency to form larger structures may affect their biological properties and bioavailability. The determined $\mathrm{MIC}, \mathrm{MBC}$ and $\mathrm{IC}_{50}$ for $\mathrm{nSiO}_{2}$ and $\mathrm{nCu} / \mathrm{SiO}_{2}$ against E. coli and $B$. subtilis are presented in Table 1. The results clearly indicated that $\mathrm{nSiO}_{2}$ was characterised by higher antibacterial activity than $\mathrm{nCu} / \mathrm{SiO}_{2}$. The smallest bactericidal activity of $\mathrm{nCu} / \mathrm{SiO}_{2}$ was recorded for $E$. coli. The $\mathrm{MIC}$, $\mathrm{MBC}$ and $\mathrm{IC}_{50}$ values confirmed the greater sensitivity of $B$. subtilis to $\mathrm{nCu} / \mathrm{SiO}_{2}$ than $E$. coli, however, the addition of $\mathrm{nSiO}_{2}$ to both bacterial cultures had a similar effect. A comparable effect was observed by Palza et al. [4], who tested the biocidal action of spherical $\mathrm{SiO}_{2}$ and $\mathrm{Cu} / \mathrm{SiO}_{2}$ on E. coli cells. Their antibacterial character was determined by the MIC and MBC values, which were 1500 and $1650 \mathrm{mg} \mathrm{L}^{-1}$ for $\mathrm{Cu} / \mathrm{SiO}_{2}$, respectively, and $>5000 \mathrm{mg} \mathrm{L}{ }^{-1}$ for $\mathrm{SiO}_{2}$. Here, the $\mathrm{MIC}$ and $\mathrm{MBC}$ values for $\mathrm{nCu} / \mathrm{SiO}_{2}$ against $E$. coli corresponded to the values $>1000 \mathrm{mg} \mathrm{L}^{-1}$. Interestingly, the MIC and $\mathrm{MBC}$ concentrations of $\mathrm{nSiO}_{2}$ in this work were 10-fold smaller in comparison with the obtained values by [4]. The stronger antimicrobial effect of $\mathrm{nSiO}_{2}$ may be associated with the irregular shape of agglomerates, which increases their biological reactivity. In another study, Adams et al. [5] reported $99 \%$ and $48 \%$ growth inhibition of $B$. subtilis and E. coli after the exposure to $5000 \mathrm{mg} \mathrm{L}^{-1}$ of $\mathrm{SiO}_{2}$. Moreover, B. subtilis was more sensitive to nanoparticles than E. coli. 

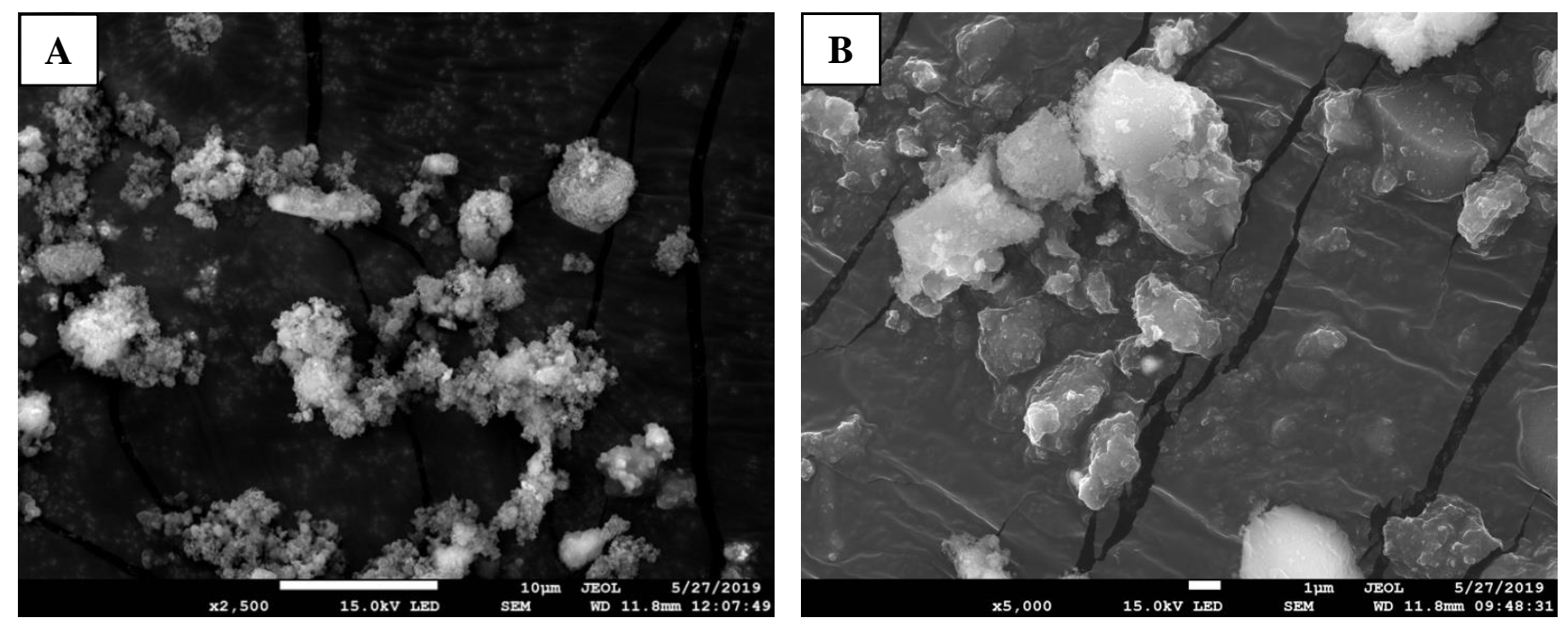

Fig. 1: Scanning electron micrographs of $\mathrm{nSiO}_{2}(\mathrm{~A})$ and $\mathrm{nCu} / \mathrm{SiO}_{2}(\mathrm{~B})$.

Table 1: The values of MIC, $\mathrm{MBC}$ and $\mathrm{IC}_{50}$ for $\mathrm{nSiO}_{2}$ and $\mathrm{nCu} / \mathrm{SiO}_{2}$ against $E$. coli and B. subtilis.

\begin{tabular}{|c|c|c|c|c|c|c|}
\hline \multirow{2}{*}{$\begin{array}{c}\text { Type of } \\
\text { nanomaterial }\end{array}$} & \multicolumn{3}{|c|}{ Escherichia coli } & \multicolumn{3}{c|}{ Bacillus subtilis } \\
\cline { 2 - 7 } & MIC & MBC & IC $_{\mathbf{5 0}}$ & MIC & MBC & IC $_{\mathbf{5 0}}$ \\
\cline { 2 - 7 } & \multicolumn{7}{|c|}{ mg L$^{-1}$} & 500 & 131,79 \\
\hline $\mathbf{n S i O}_{\mathbf{2}}$ & 500 & 500 & 90,22 & 200 & 600 & 503,22 \\
\hline $\mathbf{n C u} / \mathbf{S i O}_{\mathbf{2}}$ & $>1000$ & $>1000$ & $>1000$ & 525 & 5 \\
\hline
\end{tabular}

In order to gain more knowledge about the potential toxicity of tested nanomaterials against 11 other microorganisms, the MARA test was performed (Table 2). Both $\mathrm{nSiO}_{2}$ and $\mathrm{nCu} / \mathrm{SiO}_{2}$ exhibited low antimicrobial activity (MTC > $1000 \mathrm{mg}$ $\mathrm{L}^{-1}$ ) in relation to most tested strains. The exception was Staphylococcus warneri (8), for which a high toxicity of $\mathrm{nSiO}_{2}$ $\left(\mathrm{MTC}=435 \mathrm{mg} \mathrm{L}^{-1}\right)$ was recorded. Strains Brevundimonas diminuta (2) and $S$. warneri (8) were susceptible to the toxic effects of $\mathrm{nCu} / \mathrm{SiO}_{2}$, however, $\mathrm{nSiO}_{2}$ proved to have a twice stronger antibacterial effect on $S$. warneri $(8)$ than $\mathrm{nCu} / \mathrm{SiO}{ }_{2}$. This indicates a similar trend to those obtained for model E. coli and B. subtilis. It is also worth emphasizing that none of the tested nanomaterials, even at the highest concentration of $1000 \mathrm{mg} \mathrm{L}^{-1}$, showed no antifungal activity towards Pichia anomala (11). There are currently relatively few literature reports on the use of the MARA test to assess the toxicity of nanomaterials. An example is a study by Santos et al. [6] who reported that $\mathrm{Er}_{2} \mathrm{O}_{3}$ and $\mathrm{Ho}_{2} \mathrm{O}_{3}\left(\mathrm{MTC} 67-69 \mathrm{mg} \mathrm{L}^{-1}\right)$ were lethal to tested microorganisms. The lethal concentration of these nanomaterials was much lower than those tested in this study, therefore, each nanomaterial characterised by its own unique toxic profile should be analysed individually. Here, the tested nanomaterials demonstrated a smaller biocidal activity than the ones studied by [6], presumably due to their tendency to agglomerate. 
Table 2: The MTC values of $\mathrm{nSiO}_{2}$ and $\mathrm{nCu} / \mathrm{SiO}_{2}$ in relation to MARA microorganisms.

\begin{tabular}{|c|c|c|c|c|c|c|c|c|c|c|c|c|}
\hline \multirow[t]{2}{*}{ Type of nanomaterial } & \multicolumn{11}{|c|}{ MTC $\left[\mathrm{mg} \mathrm{L}^{-1}\right]$} & \multirow{2}{*}{$\begin{array}{c}\text { Average } \\
\text { MTC }\end{array}$} \\
\hline & 1 & 2 & 3 & 4 & 5 & 6 & 7 & 8 & 9 & 10 & 11 & \\
\hline $\mathrm{nSiO}_{2}$ & $>\max$ & $>\max$ & $>\max$ & $>\max$ & $>\max$ & $>\max$ & $>\max$ & 435 & $>\max$ & $>\max$ & $>\max$ & $>\max$ \\
\hline $\mathrm{nCu} / \mathrm{SiO}_{2}$ & $>\max$ & 847 & $>\max$ & $>\max$ & $>\max$ & $>\max$ & $>\max$ & 920 & $>\max$ & $>\max$ & $>\max$ & $>\max$ \\
\hline
\end{tabular}

1 - Microbacterium spp., 2 - Brevundimonas diminuta, 3 - Citrobacter freundii, 4 - Comamonas testosteroni, 5 - Enterococcus casseliflavus, 6 - Delftia acidovorans, 7 - Kurthia gibsonii, 8 - Staphylococcus warneri, 9 - Pseudomonas aurantiaca, 10 - Serratia rubidaea, 11 - Pichia anomala.

\section{Conclusion}

The obtained MIC, MBC and $\mathrm{IC}_{50}$ values indicated that the impact of $\mathrm{nSiO}_{2}$ and $\mathrm{nCu} / \mathrm{SiO}_{2}$ on the growth of E. coli and $B$. subtilis depended on their concentration and the species of microorganism. Despite the formation of agglomerates, the tested nanomaterials exhibited antibacterial activity, with $\mathrm{nSiO}_{2}$ having greater bactericidal activity than $\mathrm{nCu} / \mathrm{SiO}_{2}$. Furthermore, the MARA test indicated that $\mathrm{nSiO}_{2}$ and $\mathrm{nCu} / \mathrm{SiO}_{2}$ did not have antifungal activity. Undoubtedly, the obtained results confirmed a diverse impact of nanomaterials on microorganisms, however, further research is needed to explain their antimicrobial activity through multiple mechanisms including damage to the membrane and bacterial cell wall, damage to DNA, proteins and internal components, release of ions as well as oxidative stress. Detailed characteristics of these nanomaterials will enable their practical use in public nanotech products.

\section{Acknowledgements}

This study was carried out as part of Rector's Grant subvention for the best students in the 2019 edition.

\section{References}

[1] M. Sajid, M. Ilyas, C. Basheer, M. Tariq, M. Daud, N. Baig, F. Shehzad, "Impact of nanoparticles on human and environment: review of toxicity factors, exposures, control strategies and future prospects," Environ Sci Pollut Res, vol. 22, no. 6, pp. 4122-4143, 2015.

[2] J. Jeevanandam, A. Barhoum, Y. S. Chan, A. Dufresne, M. K. Danquah, "Review on nanoparticles and nanostructured materials: history, sources, toxicity and regulations," Beilstein J Nanotech, vol. 9, no. 1, pp. 1050-1074, 2018.

[3] A. Nowak, J. Szade, E. Talik, M. Zubko, D. Wasilkowski, M. Dulski, K. Balin, A. Mrozik, J. Peszke, "Physicochemical and antibacterial characterization of ionocity $\mathrm{Ag} / \mathrm{Cu}$ powder nanoparticles," Matter Charact, vol. 117, pp. 9-16, 2016.

[4] H. Palza, K. Delgado, N. Curotto, "Synthesis of copper nanostructures on silica-based particles for antimicrobial organic coatings," Appl Surf Sci, vol. 357, pp. 86-90, 2015.

[5] L. K. Adams, D. Y. Lyon, P. J. J. Alvarez, "Comparative eco-toxicity of nanoscale $\mathrm{TiO}_{2}, \mathrm{SiO}_{2}$ and $\mathrm{ZnO}$ water suspensions," Water Res, vol. 40, no. 19, pp. 3527-3532, 2006.

[6] M. A. Santos, R. T. R. Monteiro, C. Blaise, F. Gagné, K. Bull, J. F. Férard, "Influence of sediment grain size on elutriate toxicity of inorganic nanomaterials,"Water Qual Res J Can, vol. 44, no. 3, pp. 201-210, 2009. 